\title{
日本海溝周辺に扔ける太平洋プレート内の地震発生機構
}

\author{
東北大学大学院理学研究科地震・噴火予知研究観測センター* 古 賀 祥子・伊 藤 喜 宏・日 野 亮 太 \\ 東京大学地震研究所** 篠 原 雅 尚
}

東北大学大学院理学研究科地震・噴火予知研究観測センター* 海 野 徳 仁

\section{Focal Mechanisms of Small Earthquakes within the Pacific Plate near the Japan Trench}

\author{
Shoko Koga, Yoshihiro Ito, and Ryota Hino \\ Research Center for Prediction of Earthquakes and Volcanic Eruptions, \\ Graduate school of Science, Tohoku University, \\ 6-6, Aramaki-Aza-Aoba, Aoba-Ku, Sendai, 980-8578, Japan \\ Masanao SHINOHARA \\ Earthquake Research Institute, The University of Tokyo, \\ 1-1-1, Yayoi, Bunkyo-Ku, Tokyo 113-0032, Japan

\section{Norihito UMINO} \\ Research Center for Prediction of Earthquakes and Volcanic Eruptions, \\ Graduate school of Science, Tohoku University, \\ 6-6, Aramaki-Aza-Aoba, Aoba-Ku, Sendai, 980-8578, Japan
}

(Received June 17, 2011; Accepted October 24, 2011)

\begin{abstract}
A double-planed shallow seismic zone has been found in the northeastern Japan forearc region. However, the characterizations of the focal mechanisms of earthquakes in this zone, especially the lower plane events, cannot be carried out adequately due to low seismicity and poor station coverage on the focal sphere of the onshore P-wave polarity data. In this study, we determine the focal depth using the sP depth phase and the focal mechanisms using the P-wave initial motions observed by the ocean bottom cabled seismic stations and temporary autonomous ocean bottom seismic networks off Miyagi, as well as the onshore seismic networks. Seven focal mechanism solutions of events were precisely determined. Using the classification based on the dip angles of the T, B and P axes, we classified 21 weakly constrained focal mechanisms of other events having poor station coverage. All the determined solutions were of the thrustfaulting type regardless of the focal depth. The offshore observations helped considerably in constraining the focal mechanisms of these far-offshore earthquakes, especially their rake angles. Although previous studies had reported that the focal mechanisms of the upper and lower plane events show predominantly normal and reverse faulting respectively, our result showed that the thrust events in the upper plane seem to occur on the plate boundary. We found that the focal mechanisms change from normal faulting in the upper plane to reverse faulting in the lower plane at a depth of $15 \mathrm{~km}$ from the plate boundary, possibly defining the depth of the neutral plane in the northeastern Japan forearc region included in the source area of the $1933 M_{\mathrm{w}} 8.4$ Sanriku earthquake. The western edge of the normal faulting events along the upper plane is located about $70 \mathrm{~km}$ inward from the trench axis. These results suggest that the earthquakegenerating stress field in the double-planed shallow and deep seismic zone in the northeastern Japan arc can be explained by the bending-unbending model of the subducting Pacific plate.
\end{abstract}


Key words: Subduction zone, Focal mechanism, Double-planed shallow seismic zone, sP depth phase, Ocean bottom seismometer

\section{§1. はじめに}

東北日本弧では, 太平洋プレートが日本海溝から約 8 $\sim 9 \mathrm{~cm} / \mathrm{yr}$ の速度で沈み込む [DeMets et al. (1990, 1994)]. この太平洋スラブ内で発生する地震の震源分布は, ほぼ 平行な二枚の面構造を示すことが知られる [海野・長谷 川 (1975), Hasegawa et al. (1978)]. これは二重深発地 震面と称され, 深さ $70 \sim 150 \mathrm{~km}$ の範囲に分布し, 上下 二枚の面の間隔は 30 $40 \mathrm{~km}$ である。 二重深発地震面 の上面で発生する地震は, DC 型 (Down-dip Compression), 下面の地震では, DE (Down-dip Extension) 型 の発震機構解が卓越している。さらに詳細にみると, 低 角逆断層（LT）型地震が上面をなす DC 型地震より浅 部に分布し, 全体としてLT型, DC 型, DE 型の3つ の面に分かれていることが指摘されている [Seno and Pongsawat (1981)].

東北日本弧の海域下で発生する地震に関しては, 近 年, それらの震源の深さについて sP 波を用いて決定す る方法 [Umino et al. (1995)] から，東北日本弧前弧の 海域下の太平洋スラブ内においても，互いに平行な二つ の面に分かれて地震が発生していることが明らかになっ た [Gamage et al. (2009)]. このスラブ内地震の二重面 構造は, 二重浅発地震面と称され，上下面の間隔は $28-$ $32 \mathrm{~km}$ 程度であり, 深発地震面の間隔と同じかわずかに 小さい. 二重浅発地震面下面に相当する地震活動は, 福 島沖や茨城沖における海底地震計を用いた観測でも指摘 されている [Shinohara et al. (2005), 水野・他 (2009)].

Gamage et al. (2009) は, 二重浅発地震面の地震につ いて初動極性が 20 個以上得られ, 且つ震源球上での観 測点の偏りが小さい地震の発震機構解を求め, 上下面の 地震の発震機構解は, それぞれ正断層型, 逆断層型が卓 越することを示した。この二重深発・浅発地震の発生機 構を説明する有力なモデルの一つとして, 沈み込む太平 洋プレートのベンディング・アンベンディングモデルが ある [Stauder (1968a, b), Chapple and Forsyth (1979), Seno and Yamanaka (1996)]. このモデルは, 海洋プレー トが沈み込む際に折れ曲がり，その上部・下部でそれぞ れ伸長応力, 圧縮応力が作用し (ベンディング), 折れ 曲がったプレートが深部で再び平板に戻る際には，逆に 上部・下部に圧縮・伸張応力が作用する（アンベンディ ング）というものである．上・下面で逆向きの応力が働 くため, それらの間には応力の平衡域が存在する. Chapple and Forsyth (1979)によれば, 沈み込むプレー 卜内の平衡域は深さ $30 \sim 40 \mathrm{~km}$ に存在しており, Seno and Yamanaka (1996) は, 伸長応力場と圧縮応力場の境 界が海洋性プレート内の $450^{\circ} \mathrm{C}$ の等温線と良い一致を示 すと主張している。 また, Kita et al. (2010) は, スラブ 内地震の発震機構解から, 二重深発地震面の応力平衡域 が，上面から深さ $22 \mathrm{~km}$ に存在することを示した。 し かし, 沈み込むプレート内部に不均質に分布するスラブ 内地震の発生メカニズムを, ベンディング・アンベン ディングモデルのみで説明することは難しく, 近年の研 究では, 面間から下面の地震活動を脱水や含水鉱物の二 酸化炭素液化によって説明するというモデルが提唱され ている [Kirby (1995), Kirby et al. (1996), Seno and Yamanaka (1996), Peacock (2001), Yamasaki and Seno (2003)].

太平洋スラブ内の地震発生機構に関する研究はこれま でに多くなされているが, 二重浅発地震面下面の地震に ついては, その発生頻度が上面に比べ低く発震機構解の 情報が不足している。また, 二重浅発地震の震源域は陸 上の観測点から離れているため震源球上での観測点の配 置に偏りが生じることも二重浅発地震面で発生する地震 の発震機構解の推定をより困難なものとしている. そこ で, 本研究では, 2000 2009 年に発生した二重浅発地 震面の地震の発震機構解を, 陸上観測網のデータに海底 地震計 (Ocean Bottom Seismometer: OBS) のデータを 加えることにより推定し, その空間分布から太平洋スラ ブ内の応力場について議論する.

\section{§2. $\mathrm{sP}$ 波を用いた震源の深さ決定}

東北日本前弧域の沖合で発生した地震は, 震源距離約 $150 \mathrm{~km}$ 以上の陸上観測点の地震波形記録上に, 直達 $\mathrm{P}$ 波と直達 S 波の間に明瞭な $\mathrm{SP}$ 波（S 波で射出した波が 海底あるいは海底の基盤で反射変換し P 波で地上の観 測点に達する波) を示す。 Umino et al. (1995) は, sP 波 が東北日本前弧域の沖合で発生する地震の震源の深さを 精度良く決定する上で有用であることを示した， sP 波 による震源の深さの決定誤差は, 仮定する地震波速度構 造の曖昧さと, sP 波の誤認及び読み取り誤差を考慮す ると, $5 \mathrm{~km}$ 程度と見積もられている.

この sP 波の到達時刻より, Gamage et al. (2009)は, 2000～2006 年に発生した多数の地震について震源の深 さの推定を行い, 二重浅発地震面の存在を明らかにし た。本研究では, 2007 年以降に東北日本前弧域で発生 した地震について, Gamage et al. (2009) と同様の手法 で解析を行った。 


\section{1 データ}

陸上観測点（東北大学・弘前大学・北海道大学・東京 大学・気象庁・防災科学技術研究所）の 3 成分 $1 \mathrm{~Hz}$ 地 震計で記録された地震波形デー夕を用いた．解析の対象 として選んだ地震は, 2007 年 1 月から 2009 年 5 月まで に，北緯 38-40.5ㄷ東経 143-145で発生したマグニ チュード 3 以上の地震 181 個である（Fig. 1). この範囲 は, Gamage et al. (2009) が示した二重浅発地震面に属 する地震の活動度が高い領域に対応する。領域内の地震 群に対して解析に用いた観測点は，方位角で 250-300, 震央距離で 100-300 km の範囲に分布する.

\section{2 手 法}

$\mathrm{sP}$ 波の波線経路は, 震源からほぼ直上に射出され $\mathrm{P}$ 波に反射変換された後は，直達 $\mathrm{P}$ 波とほぼ同様の経路 をとる（Fig. 2)。したがって, P 波と $\mathrm{sP}$ 波の走時差 ( $\mathrm{sP}-$ $\mathrm{P}$ 時間）は震源の深さに大きく影響を受けており，それ を利用して震源の深さの正確な評価が可能となる.

本研究では, ノイズ除去のために 3 成分の地震波形に 1-4 Hzのバンドパスフィルターを施した. その後, 3 点 以上の観測点で明瞭な $\mathrm{sP}$ 波が観測された地震のみを対 象に, $\mathrm{sP}-\mathrm{P}$ 時間を観測点ごとに求めた。 $\mathrm{sP}$ 波の反射点 を海底面に仮定した 2 次元波線追跡法 [Červený and Pšenčík (1983), 岩崎 (1988)]により計算される sP-P 時 間と震源の深さとの対応関係に従って, 震源の深さを各 観測点の $\mathrm{SP}-\mathrm{P}$ 時間から求め, それらの平均をその地震 の震源の深さとした。速度構造モデルは, 陸域下では東

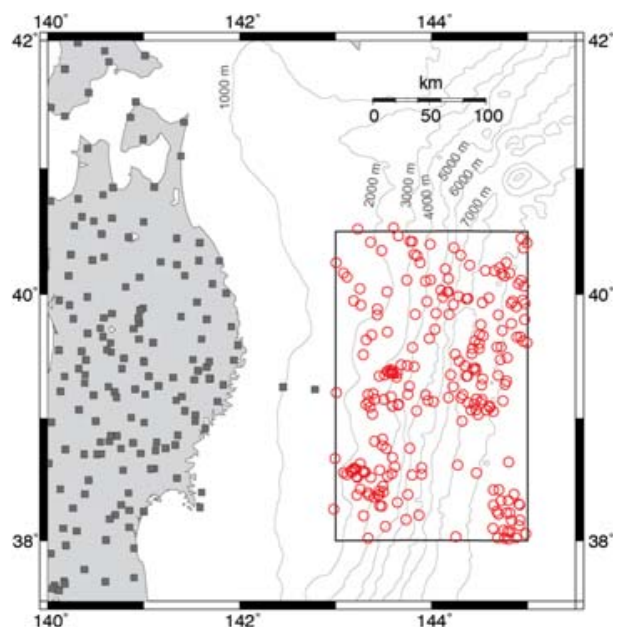

Fig. 1. Distribution of seismic stations (squares) and epicenters (circles) used in this study in the northeastern Japan arc. Black rectangle shows the study area. Contour lines indicate the depth of the ocean floor.
北大学の標準速度モデル [Hasegawa et al. (1978)], 海 域下では日本海溝を横断する測線で行われた構造探査 [Suyehiro et al. (1990)］に基づく速度モデルを使用した [Umino et al. (1995)].

本研究の解析で $\mathrm{P}$ および $\mathrm{sP}$ 波の到達時刻の読み取り に用いた波形記録例を Fig. 3 に示す.

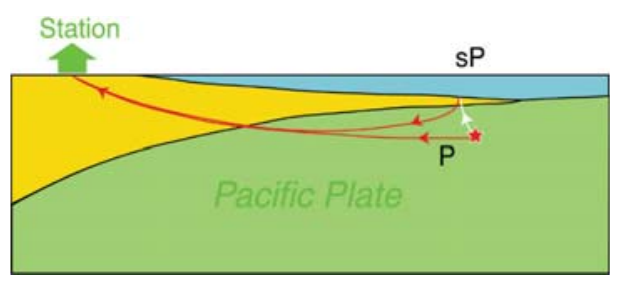

Fig. 2. Schematic ray paths of sP phases [Gamage et al. (2009)]. Red and white lines denote ray paths of direct $\mathrm{P}$ and direct $\mathrm{S}$ waves, respectively. The star shows the hypocenter and the green arrow indicates the station. The blue, yellow, and green areas denote the Pacific Ocean, North American plate/Okhotsk plate, and Pacific plate, respectively.

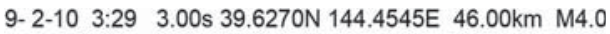

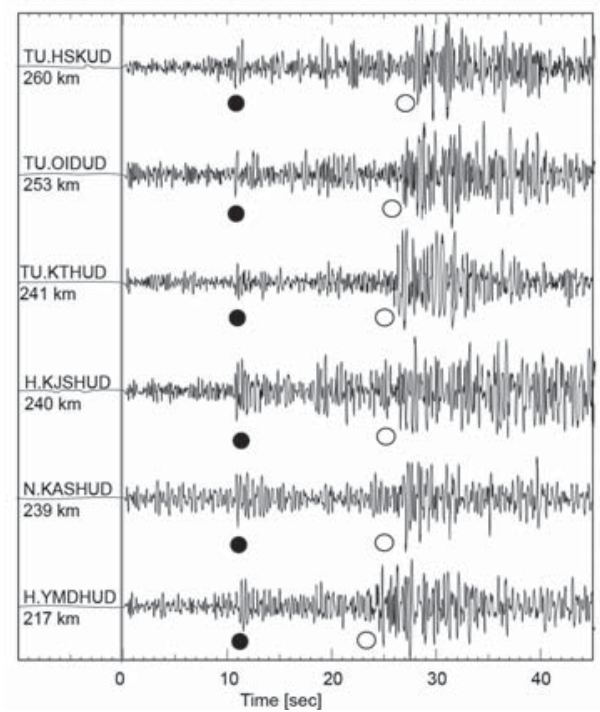

Fig. 3. Examples of vertical-component seismograms with the station name and epicentral distance. Distinct sP phases (solid circles) are observed between direct P (gray line) and S waves (open circles). The hypocenter parameters determined from the hypocenter list in the unified hypocenter catalog of the JMA are shown at the top of the seismograms. The focal depth determined from the sP phase is $23.2 \mathrm{~km}$. 


\section{3 結 果}

181 個の地震のうち 78 個の地震について, 3 観測点以 上において明瞭な $\mathrm{sP}$ 波が観測され，震源の深さの再決 定ができた. Fig. 4 には, 本研究で解析を行った 78 個 の地震の震源分布を, Gamage et al. (2009)による結果 と併せて示す。また，Fig. 5 に海溝軸に直交する方向の 鉛直断面図を示す.

震源の深さの決定誤差が $5 \mathrm{~km}$ であることを考慮する と, プレート境界面近傍の地震とそれらよりも顕著に深 い震源の深さの差は有意であり, これらの地震は二重浅 発地震面の下面に属すると考えられる。 また, 海溝軸よ り東に位置する地震は, 西に位置する地震と比較して, やや震源が深い傾向がみられた。これらの結果は Gamage et al. (2009)の結果と良く一致する.

本研究の対象領域には, 1933 年三陸地震 $\left(M_{\mathrm{w}} 8.4\right)$ の 震源とその震源域が含まれる。1 1933 年三陸地震は, 北 緯 $39.23^{\circ}$, 東経 $144.50^{\circ}$, 深さ $10 \mathrm{~km}$ で発生したプレー 卜内の正断層型地震であり [Kanamori (1971)], その震 源域周辺では現在も地震活動が活発である [Gamage et al. (2009)]. Gamage et al. (2009) は, この地震の震源域 内では地震が二重浅発地震面の面間でも発生しており, 海溝軸下の深さ $21 \mathrm{~km}$ より浅い地震は正断層型の発震 機構解をもつ傾向にあることを示した。本研究の結果で

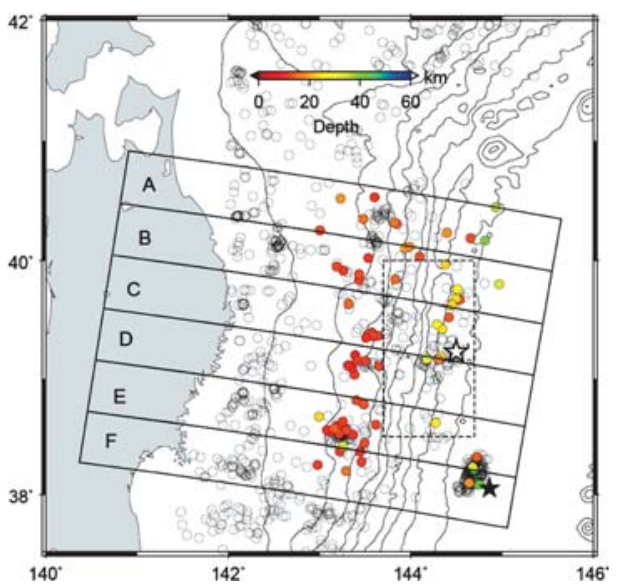

Fig. 4. Epicenter distribution of relocated earthquakes in this study (colored circles). The color scale of the circles represents a focal depth of the earthquake. Gray circles show earthquakes determined by Gamage et al. (2009). Contour lines indicate the depth of the ocean floor. The open star and dashed rectangle represent the epicenter and source region of the 1933 Sanriku earthquake, respectively. The solid star represents the epicenter of the 2005 Sanriku earthquake $\left(M_{\mathrm{w}} 7.0\right)$.
も，震源域を含む断面 B-Eにおいては震源域下で発生 している地震は深さ $40 \mathrm{~km}$ 付近まで幅広く分布してお り, 他の断面に比べて, 浅発二重地震面の上下面の間で も多くの地震が発生していることが確かめられた.

\section{$\S 3 . \quad$ 地震発生機構}

本研究の対象である二重浅発地震面の地震の発震機構 を明らかにし，その傾向を知ることは，沈み込んで間も ない，比較的浅部にある太平洋プレート内の応力場状態 を知る上で重要である。しかしながら, 二重浅発地震面 下面での地震の発生頻度が低いことと, これらの地震に ついては震源-観測点間の距離が大きく，また観測点配 置に偏りがあるため, 発震機構解を精度良く求めること が難しい。

本研究では，2003～2009 年に発生した地震を対象に, 陸上地震観測に加えて, OBSの波形データを用い, $\mathrm{P}$ 波の初動極性から発震機構解を求めた。本研究と先行研 究で得られた発震機構解をあわせて, 断層夕イプで分類 し [Frohlich (1992)], その空間分布から, 太平洋スラ ブ内の応力場について議論する.

\section{1 データ}

陸上観測点及びケーブル式海底地震計（東北大学・弘 前大学・北海道大学・東京大学・気象庁 - 防災科学技術 研究所）によるリアルタイム連続観測による地震波形 デー夕, および OBS（東北大学, 東京大学, 気象庁) を用いた臨時観測で記録されたデー夕の鉛直成分から P 波初動極性を読み取った。解析では，各地震に対して震 央距離が $300 \mathrm{~km}$ 以下の観測点のみを使用した.

2003 2006 年に発生した地震については，17個の二 重浅発地震面下面の地震を対象に解析を行った。 これら の震源の深さは Gamage et al. (2009)により sP-P 時間 から再決定されているが, 発震機構解が未決定であった ものである.ささらに, 本研究で震源の深さの決定を行っ た 2007〜2009 年に発生した 78 個の地震についても同様 の解析を行った。観測点と解析対象とした地震の分布を Fig. 6 に併せて示す

\section{2 発震機構解の決定}

30 観測点以上で $\mathrm{P}$ 波初動極性を読み取ることができ た地震を対象として, 節面の走向, 傾斜角およびすべり 角をそれぞれ $3^{\circ}$ 刻みで変えながらグリッドサーチ［Ito et al. (2005)] によって発震機構解を求めた。震源から各 観測点に至る波線の射出角の計算には，松澤・他 (1994) による地震波速度構造モデル (Fig. 7) を使用した. 得ら れた解の中から精度が良いもののみを選別するため，以 下の基準を設けた。

1. 観測された初動極性と最適解から期待される初動 

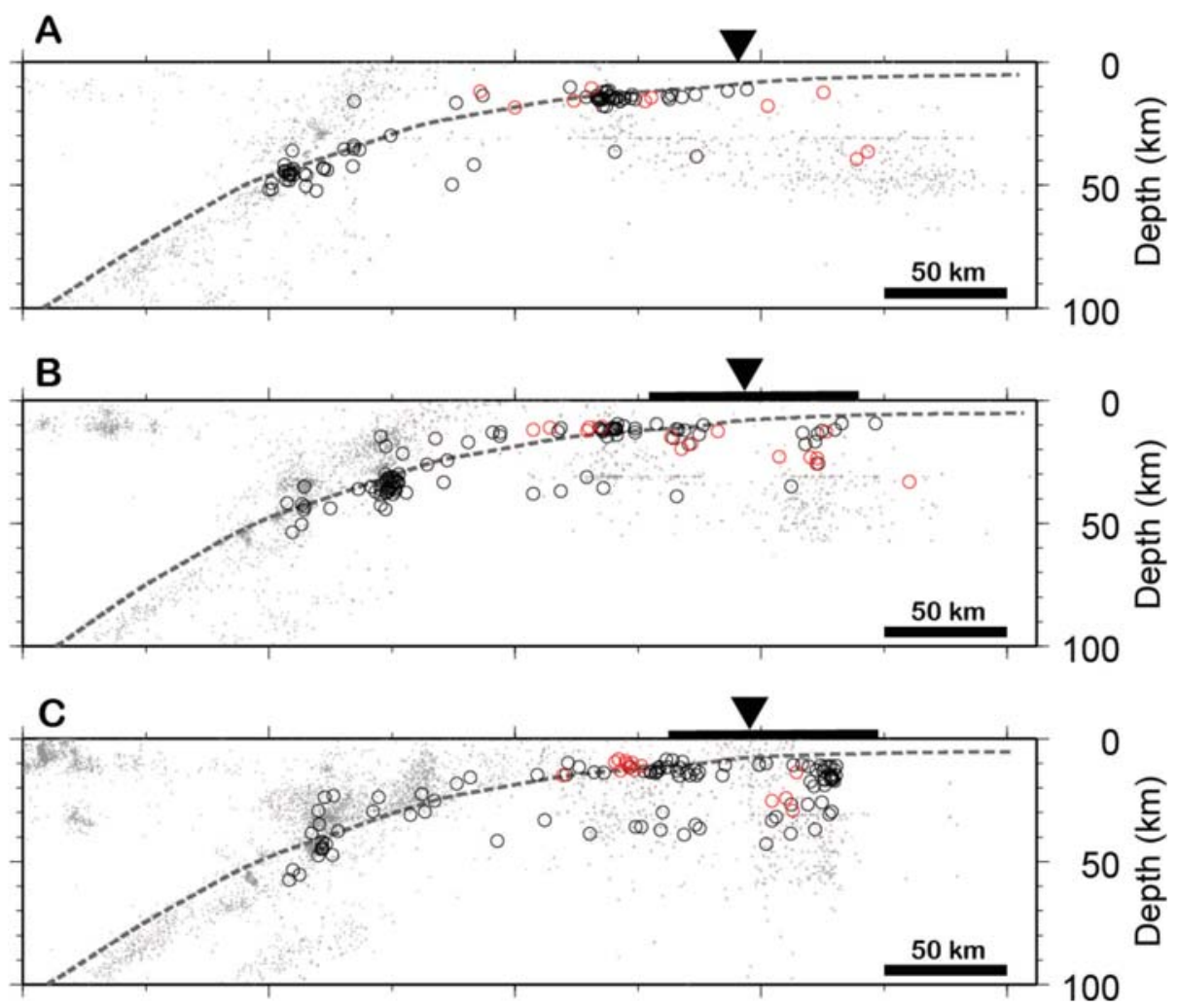

Fig. 5. Across-arc vertical cross-sections of earthquakes relocated in the present study (red circles) and by Gamage et al. (2009) (black circles). Gray dots represent the earthquakes determined by the Tohoku University network for the period from 2000 to 2007. The locations of the cross-sections are shown in Fig. 4. The thick, horizontal lines at the top of cross sections B-E denote the location of the aftershock area of the $1933 M_{\mathrm{w}} 8.4$ Sanriku earthquake. The dashed line denotes the plate boundary [Nakajima et al. (2009), Ito et al. (2004)]. Inverted triangle denotes the location of the trench.

極性との不一致の数が全デー夕数の $10 \%$ 以下である.

2. 初動極性データを得た観測点間の震源球面上で 測った角度の最大が $90^{\circ}$ 以上である。

\section{3 発震機構解の分類}

個別の地震に対して推定された発震機構解から, 震源 周辺の応力状態を推定するには, それぞれの解の間の共 通性を見出すことが必要である。そのために, P 軸・T 軸・B軸の俯角に関する三角ダイアグラム [Frohlich (1992)]を用いて, 得られた発震機構解を応力状態の違 いに対応させることができるような分類を行った。この 手法は, 初動極性データで発震機構解を一意に決定する ことが難しい地震に対して, その代表解を求めるために も応用できる，発震機構解に対する制約が十分でない場 合, 観測データを同程度に説明できる解が複数存在す る.ここでは, そうした地震のうち，30 観測点以上で 初動極性データが得られているものに対し, 得られた複
数の候補解から三角ダイアグラム中の座標を求め, その 平均をもって, その地震の代表值とした。ここで示す発 震機構解の代表值は, 対象とする地震が逆断層型, 正断 層型，横ずれ型のどのタイプに分類されるかを示すもの であり, 複数得られた候補解の平均值と必ずしも一致し ない.

\section{4 結 果}

解析の対象とした 95 個の地震のうち, 30 以上の観測 点で $\mathrm{P}$ 波初動極性を読み取ることができたものは 28 個 で, うち 7 個の地震について精度の良い発震機構解が得 られ，21個の地震については，複数の候補解から代表 值を求めた (Fig. 8). 本研究で求めた 28 個の地震の発 震機構解を Fig. A1 に示す.

本研究の発震機構解の推定では, OBSのデータを加 えることにより解の安定化を図った。 Fig. 9 に, 陸上観 測点のみを使用して推定した発震機構解と, 同じ地震に 

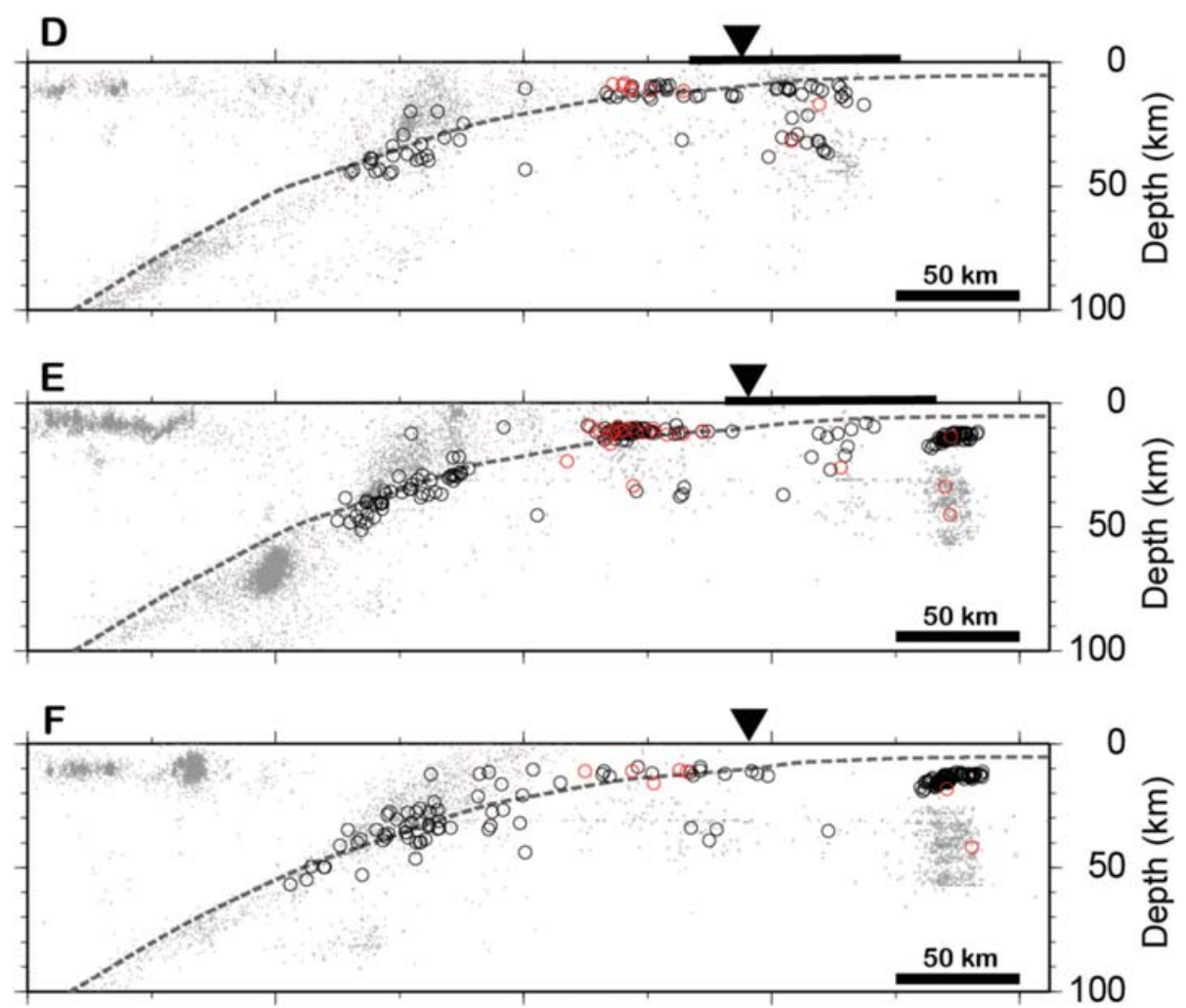

Fig. 5. Continued.

ついて OBS のデータを加えた結果得られた解の比較を 示す。この地震の場合, OBSのデータを加えることで, 陸上観測点のデータだけでは区別することができない大 きく異なる候補解が，ほぼ1つに絞られた。これは, OBS の数が少なくとも, 陸上観測点と比較すると震源 域付近に存在し，震源から見た方位角が大きく異なるた め, そのデータが発震機構解の推定に有効であることを 示している. 本研究の解析結果では, 特にすべり角を決 定する上で OBS のデータが有効であった．

本研究で求めた発震機構解は, やや横ずれ成分を含む ものの, いずれも大局的には逆断層型の地震であった. そのうち二重浅発地震面の上面に属する地震の発震機構 解は 11 個で，いずれも低角逆断層型に分類できる。一 方, 下面に属する地震については, 発震機構解の得られ た 17 個の地震いずれについても逆断層成分に富む解が 推定されており, 下面では逆断層型の地震が卓越するこ とを示している。

Fig. 10 は, Fig. 8 で示した発震機構解の分布に, Gamage et al. (2009) および Kita et al. (2010)により推定され たスラブ内地震の発震機構解の分布を重ねて示した。 海
溝軸近傍においては, 正断層型の発震機構解をもつ浅い 地震と逆断層型の深い地震の境界は, プレート境界 [Nakajima et al. (2009), Ito et al. (2004)］から深さおよそ $15 \mathrm{~km}$ 程度である。そこで, プレート境界からの深さ $15 \mathrm{~km}$ 未満の地震を上面の地震, それ以上の地震を下面 の地震として区別した (Fig. 11). 上面では, 正断層型地 震と低角逆断層型地震がプレート境界型地震のアスペリ ティ [山中 (2003), Yamanaka and Kikuchi (2004)] の周 囲に位置する。また, 海溝軸から陸側約 $70 \mathrm{~km}$ の範囲 では, 正断層型の地震が卓越する。一方, 下面では, 逆 断層型地震が海溝陸側斜面で海溝に平行に分布し, 山中 (2003) および Yamanaka and Kikuchi (2004) で示された アスペリティ下で発生しているものも存在した. 宮城沖 ではアスペリティの西側で正断層型地震が多く発生して いる.

\section{$\S 4$. 議 論}

本研究により, 東北日本前弧の二重浅発地震面は, 上 面で低角逆断層型地震と正断層型地震, 下面で逆断層型 地震が発生していることがわかった。これらの発震機構 


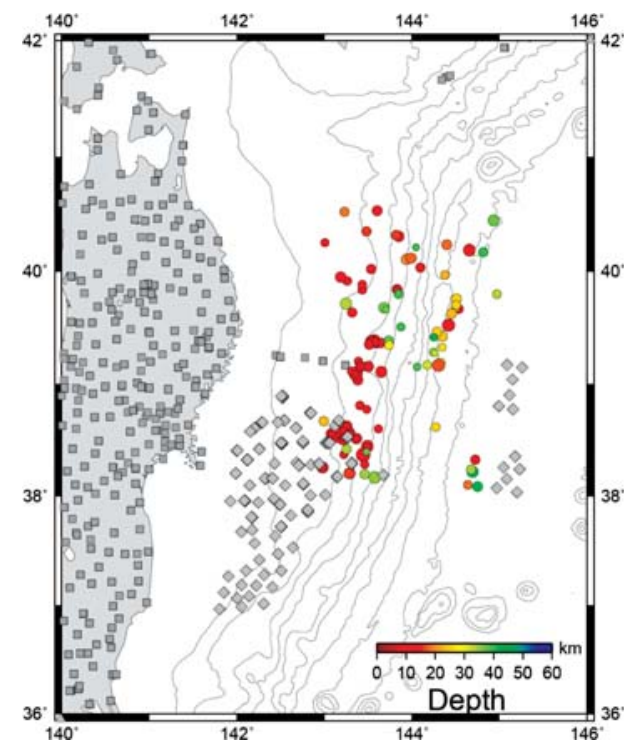

Fig. 6. Distribution of seismic stations (squares and diamonds) and epicenters (circles) used in the focal mechanism analysis. The color scale of each circle represent the focal depth. The contour lines indicate the depth of the ocean floor and the diamonds represent the location of the OBSs used in this study.

解の分布は以前から提唱されてきたプレートのベンディ ング・アンベンディングモデルを支持する結果であった。

上面の地震については, Gamage et al. (2009)により 正断層型地震が卓越することが報告されていたが, 本研 究の解析では, 発震機構解を推定することができた上面 の地震はいずれも, 低角逆断層型であった. 本研究では, 海底地震計が設置されていた期間内に解析対象とした領 域内で発生した地震についてのみ発震機構解を求めた。 この期間内では二重浅発地震面の上面で発生した地震数 が少なく, これが本研究において正断層型地震を検出で きなかった一因かもしれない. 本研究で得られた上面の 発震機構解の節面の一方は, 震源付近におけるプレート 境界面と同様の傾斜角をもつことから，プレート境界型 地震と解釈される。これらの震源の深さは, Nakajima et al. (2009) や Ito et al. (2004)によるプレート境界面よ りやや浅くなっているが, sP 波の読み取り精度や, 本 研究で深さの再決定に用いた速度構造と Nakajima et al. (2009) および Ito et al. (2004) らがプレート境界推定に用 いた速度構造との違いを考慮すると, この深さの差に関 する詳細な議論はできない.

Gamage et al. (2009) は, 二重浅発地震面の上面で正 断層型地震が卓越する原因を, 沈み込む太平洋プレート
Velocity $(\mathrm{km} / \mathrm{s})$

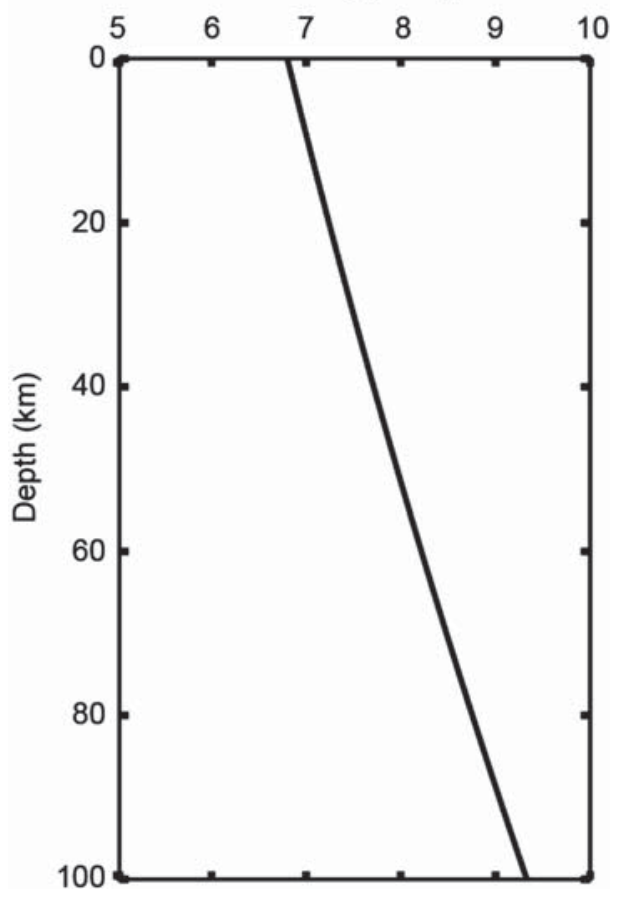

Fig. 7. P-wave velocity structure model for the calculation of take-off angles from hypocenters to stations [Matsuzawa et al. (1994)].

のベンディングによって説明し, それらの地震はプレー トの表面に沿う方向の伸長応力の影響をうけて発生する 海洋プレート内の地震であると解釈した。特に沈み込む 太平洋プレートのベンディングの効果が顕著な場所とし て，海溝軸とそれよりも 70〜 $80 \mathrm{~km}$ 陸側でプレートの 沈み込み角度が大きくなる “sharp bending point”を指 摘している (Fig. 12). 本研究では二重浅発地震面の分布 域が海溝軸よりも陸側にあることを確認した。また, “sharp bending point” 付近で上面の正断層型地震より 浅い側に, プレート境界型と考えられる低角逆断層地震 が発生していることを確認した。この結果は, 深発地震 面について報告されているような, LT 型, DC 型, DE 型の 3 面構造 [Seno and Pongsawat (1981)] が, “sharp bending point”付近の二重浅発地震面についても形成 されている可能性を示唆する.

本研究により, 二重浅発地震面下面の地震に対して推 定された発震機構解は, いずれも逆断層成分が卓越する ものであった。この結果も, Gamage et al. (2009)が指 摘している下面の地震が示す特徴と一致しており, その 力学的原因を太平洋プレートのベンディングによって説 明する考えを支持するものである. 
(a)

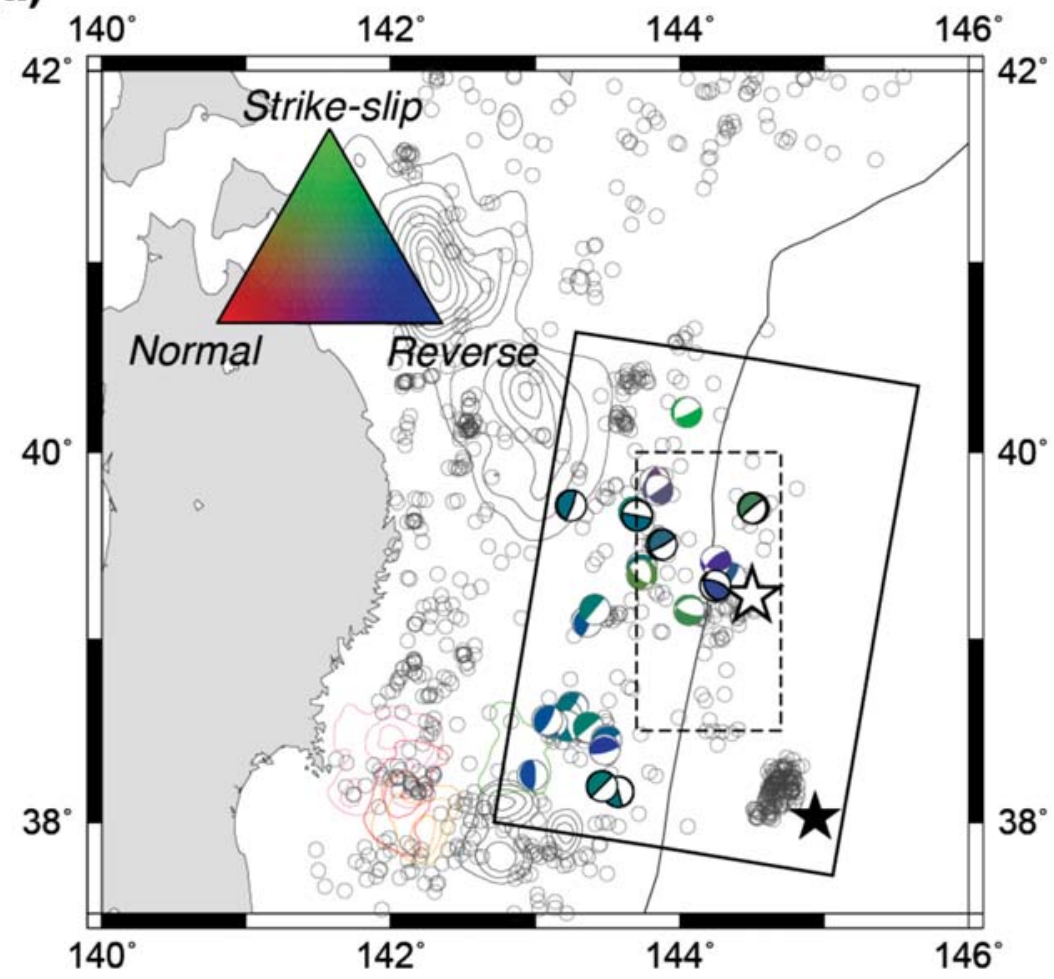

(b)

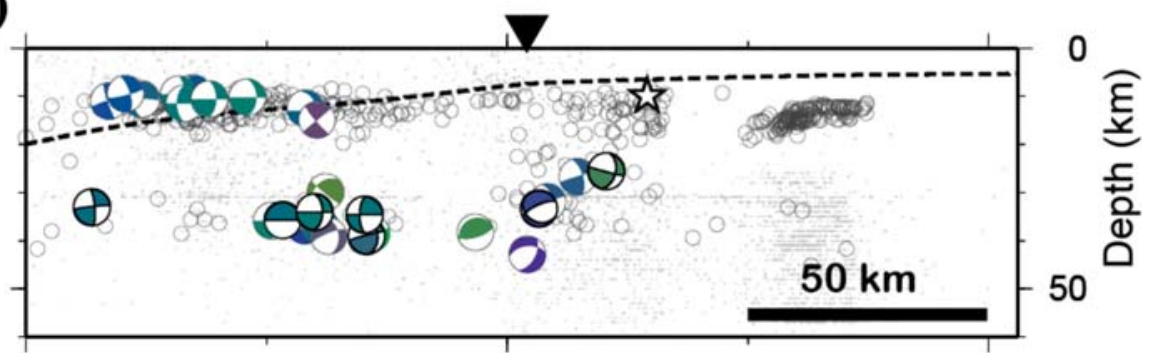

Fig. 8. (a) Distribution and (b) vertical cross-section of the rectangle shown in (a) of the focal mechanism solutions in this study. The color scale of each focal mechanism solutions corresponds to the triangle diagram in (a). The focal spheres drawn with solid lines indicate the focal mechanism solutions determined precisely in this study. Gray circles show earthquakes determined by the sP depth phase. Open star and dashed rectangle in (a) represent the epicenter and source region [Kanamori (1971)] of the 1933 Sanriku earthquake, respectively. The solid star represents the epicenter of the 2005 Saniriku earthquake. Black line and color contour lines indicate the trench and asperities of the plate boundary earthquakes [Yamanaka (2003), Yamanaka and Kikuchi (2004)]. Inverted triangle and dashed line in (b) denote the location of the trench and the plate boundary [Nakajima et al. (2009), Ito et al. (2004)], respectively. Gray dots represent the earthquakes determined by the Tohoku University network from 2000 to 2007.

また本研究により，1933 年三陸地震の余震域内を含 むより広い範囲で下面の逆断層地震を見いだすことがで きた. Gamage et al. (2009)による正断層型地震の深さ の下限と本研究で得られた逆断層型地震の深さの上限か ら, 正断層型／逆断層型の転移が生じる位置は, プレー
卜境界あるいは海底面から拈よそ $15 \mathrm{~km}$ 下方と推定さ れる (Fig. 10)。この転移の深さは, スラブ上部での正 断層地震を発生させる伸長応力場と, 下部での逆断層型 地震を発生させる圧縮応力場との間に存在する, 応力中 立面の深さに対応する. 本研究の解析対象領域南東のア 
(a)

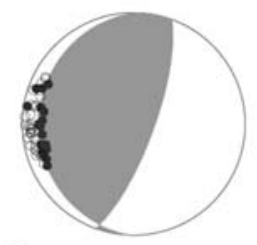

(b)

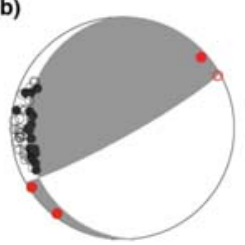

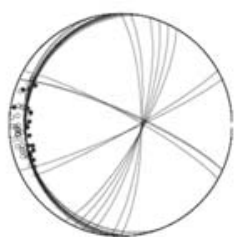

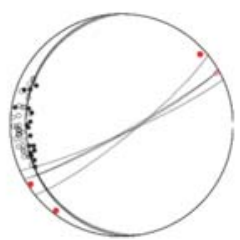

Fig. 9. Examples of the focal mechanism solutions determined from $\mathrm{P}$-wave initial motions recorded by (a) onshore seismic networks and (b) onshore seismic networks and OBS data. Left and right figure represent best solutions and candidate solutions. The black solid and open circles denote the compression and dilatation of the initial Pwave motions observed in the onshore seismic networks, respectively. The red solid and open circles denote the compression and dilatation of the initial P-wave motions observed in the OBS, respectively.

ウターライズ域では, 2005 年に $M 7.0$ の地震が発生して いるが, その破壊域の深さ方向の拡がりは，海底下 $15-$ $20 \mathrm{~km}$ [Hino et al. (2009)] で, Fig. 10 で示した正断層 型地震の深さの下限とほぼ一致する。この地震の破壊域 の下限が応力場によって規定されているとすれば, 日本 海溝外側の太平洋プレート内で張力場にある領域の厚さ はほぼ一定と考えることができる。一方, 東北日本の深 発二重面において, Kita et al. (2010) は上面側の圧縮場 と下面側の伸長場との間の応力中立面がプレート境界面 からおよそ $22 \mathrm{~km}$ 下方にあると指摘している。本研究 の結果と比較すると, 推定された中立面の深さはわずか に深いが，それぞれでの中立面の位置の推定誤差を考慮 すると, この差が有意なものであるかは検討の余地があ る.しかし, このようにして, 海溝軸付近と, 深く沈み 込んだ後の太平洋スラブ内の応力状態を比較できる可能 性が示された意義は大きい.これら応力状態の概念図を Fig. 12 に示す.

本解析の結果, 新たに求めた地震の発震機構解は上下 面全て逆断層型の傾向を持ち, 海溝軸陸側斜面から海側 斜面にかけて東西に幅広く分布していた。これは, Gamage et al. (2009) の解析結果が, 上面の地震の発震 機構解が全て正断層で, 下面の地震の発震機構解が東経 $144^{\circ}$ より西では得られていないことと対照的である。そ

の要因としては，陸上観測網のデータにOBSのデータ を追加したことと, 発震機構解の分類を行ったことが考 えられる。遠く沖合の浅い地震の発震機構解を陸上の観 測データからだけで推定する場合, 震源球面上での射出 角の拡がりが小さくなるため困難であり, 地震が低角逆 断層型の発震機構をもつ場合には, 一意な解を求めるこ とがとりわけ難しい. しかし，OBSのデータを加える ことにより初動極性データが得られる方位角範囲が広が り, より多くの低角逆断層型の発震機構解が決定するこ とができた。また, 三角ダイアグラムを応用して, 従来, 発震機構解の制約が効きにくかった地震についても，合 理的に代表的な解を推定できるようにしたことも，発震 機構解が決定可能な地震の数を増やすことに寄与した.

\section{$\S 5$. 結 論}

本研究では, 従来の研究により上面で正断層型地震, 下面で逆断層型地震の発生が指摘されてきた, 東北日本 沈み込み帯の浅部二重地震面の地震を対象に震源決定を 行い, それらについて海底・陸上観測網を併せて用いて 発震機構解を求めた。 その結果, 以下の新しい観測結果 を得た。

1. 二重浅発地震面上面には, 従来存在が確認されて いた正断層型地震に加えて, プレート境界型地震に対応 する低角逆断層型の地震も含まれる。

2. 1933 年三陸地震の震源域において, 二重浅発地 震面下面に相当する深さで逆断層型地震が発生している.

3. 1933 年三陸地震の震源域では, 二重浅発地震面 の上下面との間にも地震が発生しており, プレート境界 からの深さ約 $15 \mathrm{~km}$ を境に浅部側に正断層型地震, 深 部側に逆断層型地震が分布する.

これらの観測結果は, 二重浅発地震面の形成を説明す る大局的な応力場がプレートのベンディング・アンベン ディングモデルにより説明できることを強く支持する. さらに, 沈み込み带浅部のスラブ内応力場として, プ レート境界から深さおよそ $15 \mathrm{~km}$ にある応力平衡域を 境界として, それより浅部では伸長応力, 深部では圧縮 応力がそれぞれ支配的であることが示された.

\section{謝辞}

本研究では, 北海道大学・弘前大学・気象庁および防 災科学技術研究所により取得されている地震記録を用い ました. Shantha S.N. Gamage 博士と北 佐枝子博士に 提供していただいた発震機構解のデータを使用しまし た。一部の困の作成にはWessel and Smith (1998)の Generic Mapping Tools を使用しました。記して感謝い たします。 
(a)

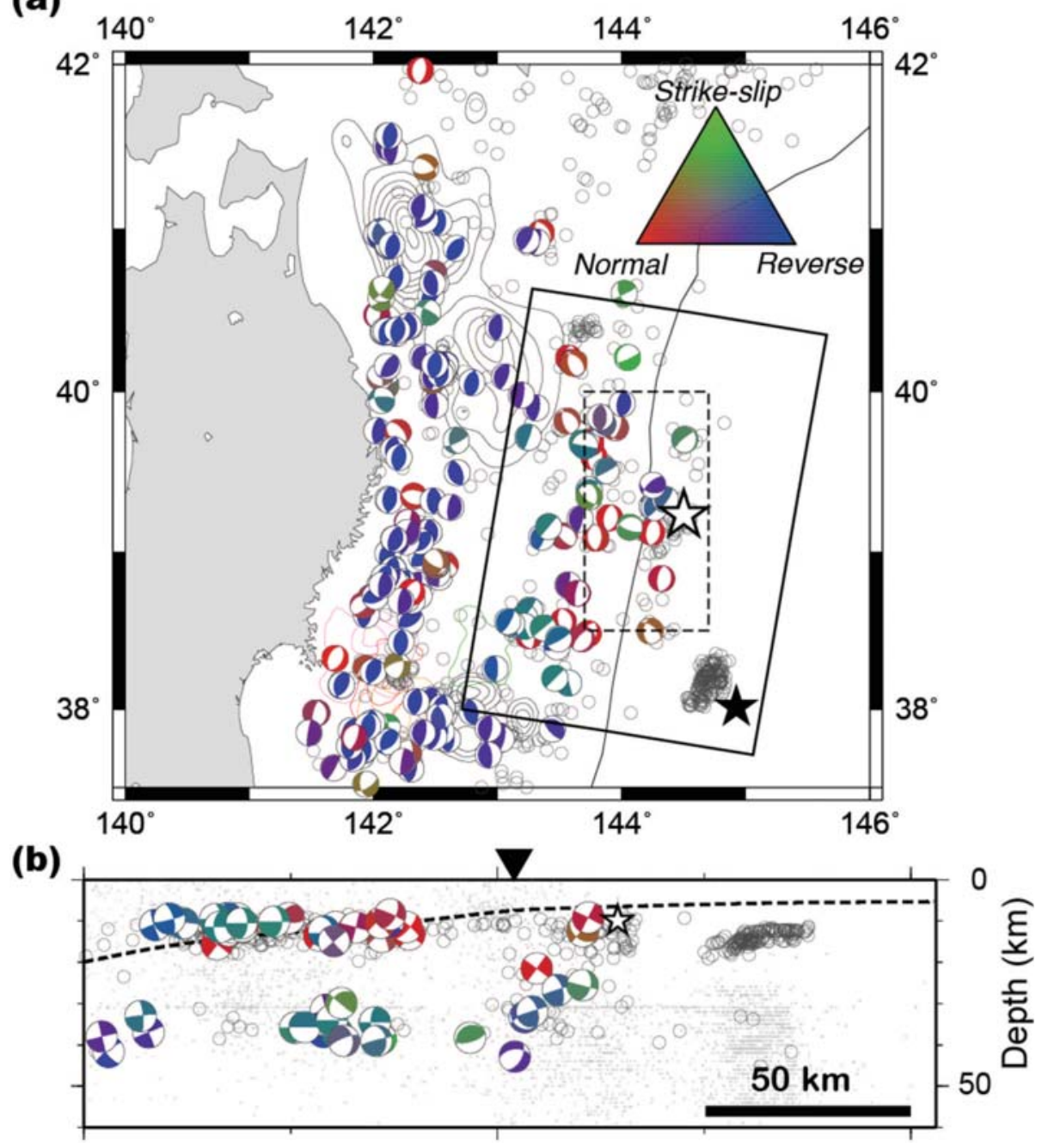

Fig. 10. (a) Distribution and (b) vertical cross-section in the rectangle shown in (a) of the focal mechanism solutions obtained in this study, and in the studies of Gamage et al. (2009) and Kita et al. (2010). Others are the same as Fig. 8 . 
(a)

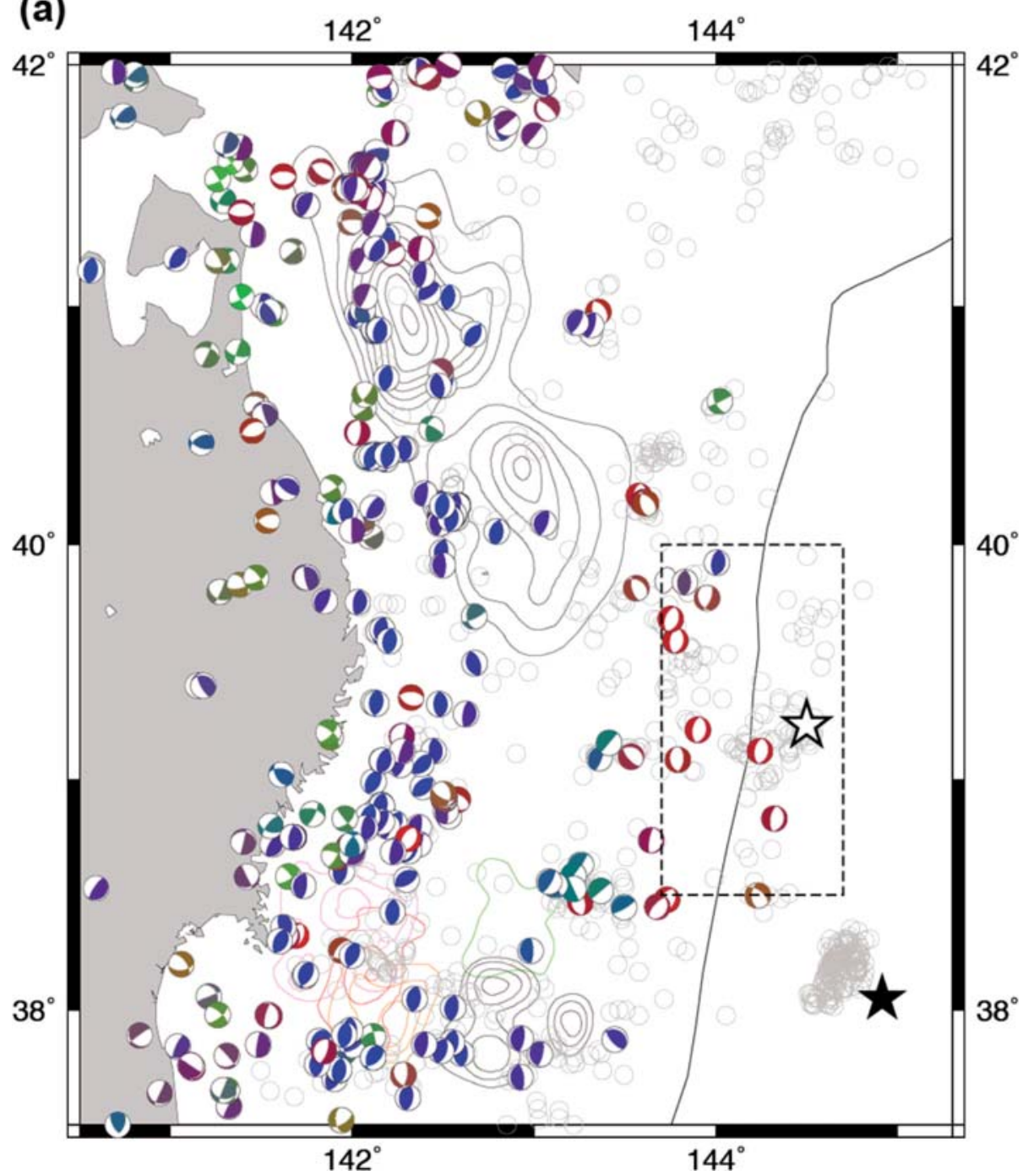

Fig. 11. (a) Distribution of the focal mechanism solutions whose depth from the plate boundary is less than $15 \mathrm{~km}$, obtained in this study, and in the studies of Gamage et al. (2009) and Kita et al. (2010). The color scale of the focal mechanism solutions corresponds to the triangle diagram. Gray circles show earthquakes determined by the sP depth phase. (b) Distribution of the focal mechanism solutions whose depth from the plate boundary is more than $15 \mathrm{~km}$, determined in this study and in the studies of Gamage et al. (2009) and Kita et al. (2010). Others are the same as Fig. 8. 


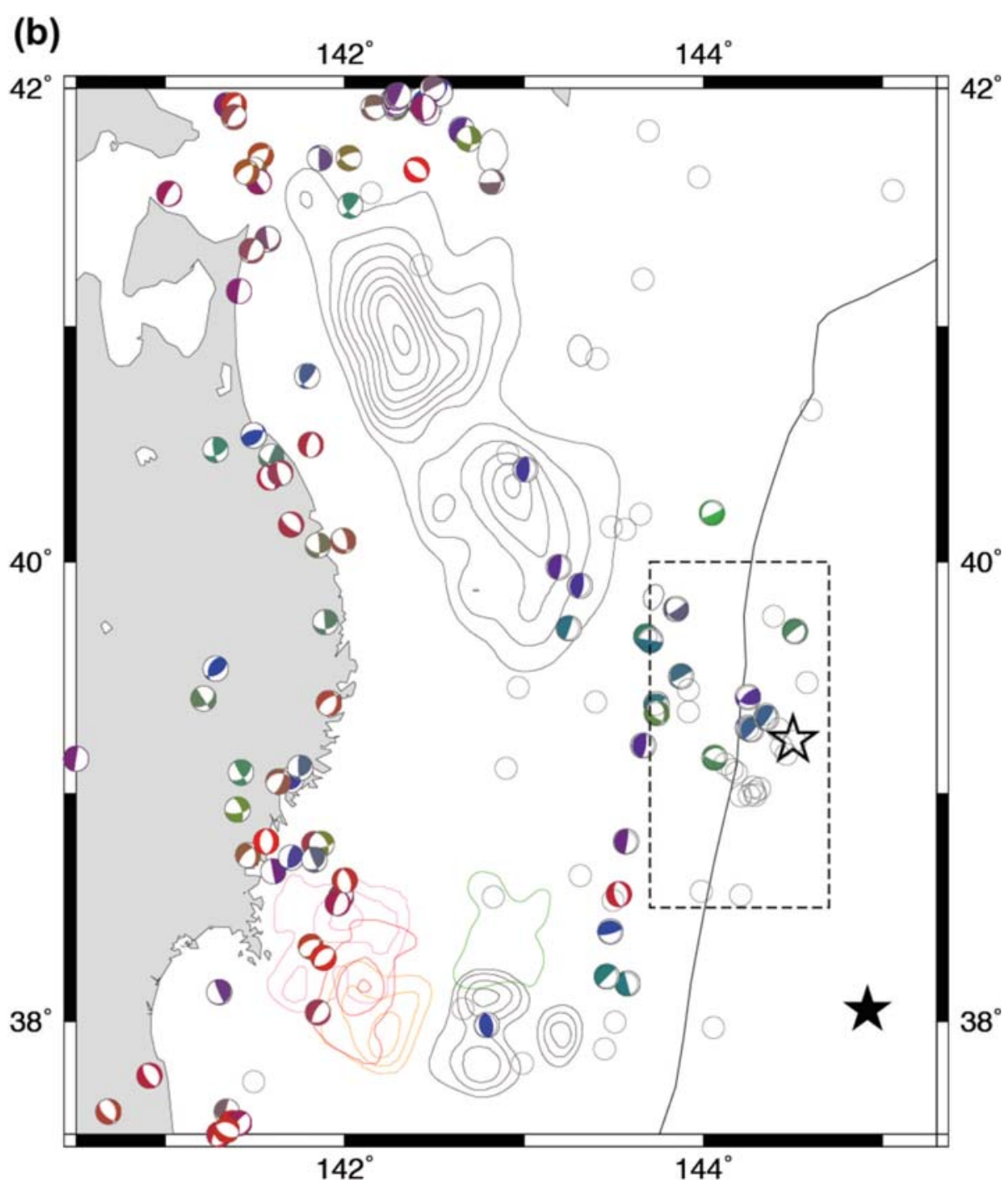

Fig. 11. Continued. 


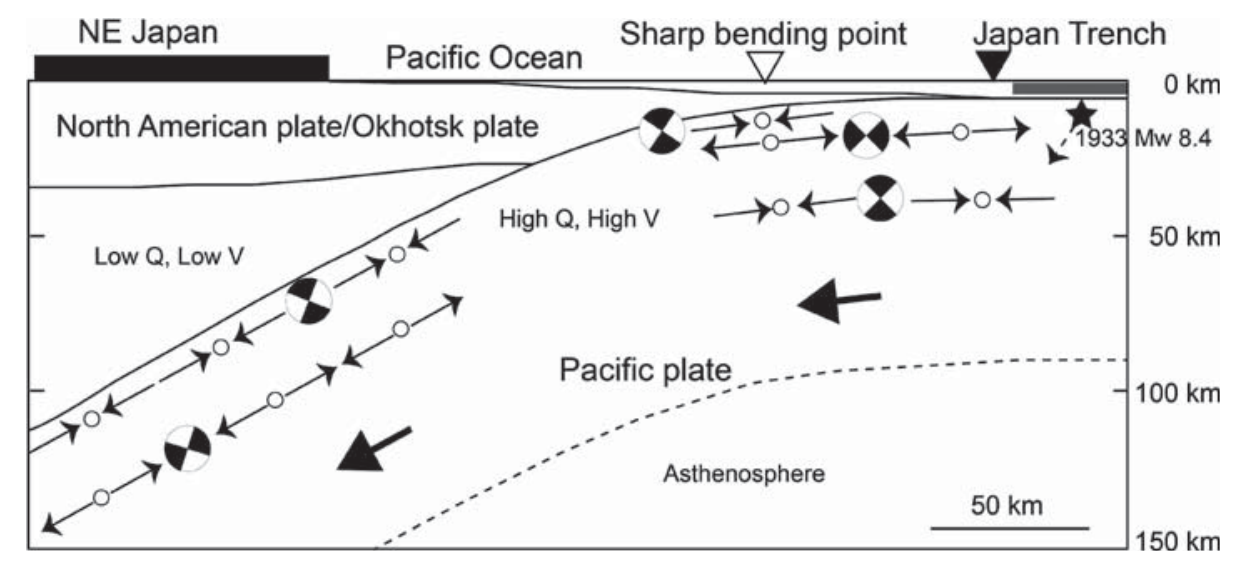

Fig. 12. Schematic illustration of the bending-unbending model, showing earthquake-generating stresses within the Pacific plate. Typical focal mechanisms are projected on the wall-side focal hemisphere using an equal area projection. Small open circles and thin arrows show hypocenter and earthquake-generating stress, respectively. Thick arrows show the subduction motion of the Pacific plate. The location of the outer rise region is shown by the thick grey line. Open and solid reverse triangles show the location of a sharp bending line of the Pacific plate [Fujie et al. (2006)] and the Japan Trench, respectively.

\section{文献}

Červeny, V. and I. Pšenčík, 1983, A 2-D seismic ray package, SEIS83, Charles University, Prague.

Chapple, W. and D. Forsyth, 1979, Earthquakes and bending of plates at trenches, J. Geophys. Res., 84, 6729-6749.

DeMets, C., R.G. Gordon, D.F. Argus, and S. Stein, 1990, Current plate motions, Geophys. J. Int., 101, 425-478.

DeMets, C., R.G. Gordon, D.F. Argus, and S. Stein, 1994, Effect of recent revisions to the geomagnetic reversal time scale on estimates of current plate motions, Geophys. Res. Lett., 21, 2191-2194.

Frohlich, C., 1992, Triangle diagrams: ternary graphs to display similarity and diversity of earthquake focal mechanisms, Phys. Earth Planet. Inter., 75, 193-198.

Fujie, G., A. Ito, S. Kodaira, N. Takahashi, and Y. Kaneda, 2006, Confirming sharp bending of the Pacific plate in the northern Japan trench subduction zone by applying a traveltime mapping method, Phys. Earth Planet. Inter., 157, 72-85.

Gamage, S.S.N., N. Umino, A. Hasegawa, and S.H. Kirby, 2009, Offshore double-planed shallow seismic zone in the NE Japan forearc region revealed by sP depth recorded by regional networks, Geophys. J. Int., 78, 195-214.

Hasegawa, A., N. Umino, and A. Takagi, 1978, Doubleplaned structure of the deep seismic zone in the northeastern Japan arc, Tectonophysics, 47, 43-58.

Hino, R., R. Azuma, Y. Ito, Y. Yamamoto, K. Suzuki, H. Tsushima, S. Suzuki, M. Miyashita, T. Tomori, A. Arizono, and G. Tange, 2009, Insight into complex rup- turing of the immature bending normal fault in the outer slope of the Japan Trench from aftershocks of the 2005 Sanriku earthquake $\left(M_{\mathrm{w}}=7.0\right)$ located by ocean bottom seismometry, Geochem. Geophys. Geosyst., 10, Q07O18, doi:10.1029/2009GC002415.

Ito, A., G. Fujie, T. Tsuru, S. Kodaira, A. Nakanishi, and Y. Kaneda, 2004, Fault plane geometry in the source region of the 1994 Sanriku-oki earthquake, Earth Planet. Sci. Lett., 223, 163-175.

Ito, Y., T. Matsumoto, H. Kimura, H. Matsubayashi, K. Obara, and S. Sekiguchi, 2005, Spatial distribution of centroid moment tensor solutions for the 2004 off Kii peninsula earthquakes, Earth Planets Space., 57, 351356.

岩崎貴哉, 1988 , 海底地震探査に基づく地下速度構造研 究のための波線追跡プログラム, 地震 2, 41, 263-266.

Kanamori, H., 1971, Seismological evidence for a lithospheric normal faulting - the Sanriku earthquake of 1933, Phys. Earth Planet. Inter., 4, 289-300.

Kirby, S. H., 1995, Intraslab earthquakes and phase changes in subducting lithosphere, Rev. Geophys. 33, 287-297.

Kirby, S.H., E.R. Engdahl, and R. Denlinger, 1996, Intermediate-depth intraslab earthquakes and arc volcanism as physical expressions of crustal and uppermost mantle metamorphism in subducting slabs, in "Subduction Top to Bottom", ed. by G.E. Bebout, Geophys. Monogr. Ser., 96, AGU, Washington, D.C., 195214.

Kita, S., T. Okada, A. Hasegawa, J. Nakajima, and T. Matsuzawa, 2010, Existence of interplane earthquakes and neutral stress boundary between the up- 
per and lower planes of the double seismic zone beneath Tohoku and Hokkaido, northeastern Japan, Tectonophysics, 496, 68-82.

松澤 暢・海野徳仁・長谷川 昭・本谷義信・小平秀 一・佐藤魂夫・小菅正裕, 1994, 併合処理による三陸 沖の地震活動 (2), 日本地震学会講演予稿集 1994 年 度秋季大会, B52.

水野真理子 - 佐藤利典 - 篠原雅尚 - 望月公廣 - 山田知 朗・金澤敏彦，2009，長期観測型海底地震計を用いた 茨城沖における海溝外縁部の自然地震活動, 地震 2 , 62, 19-23.

Nakajima, J., Y. Tsuji, and A. Hasegawa, 2009, Seismic evidence for thermally-controlled dehydration reaction in subducting oceanic crust, Geophys. Res. Lett., 36, L03303, doi:10.1029/2008GL036865.

Peacock, S.M., 2001, Are the lower planes of double seismic zones caused by serpentine dehydration in subducting oceanic lithosphere?, Geology, 29, 299-302.

Seno, T. and B. Pongsawat, 1981, A triple-planed structure of seismicity and earthquake mechanisms at the subduction zone off Miyagi Prefecture, northern Honshu, Japan, Earth Planet. Sci. Lett., 55, 25-36.

Seno, T. and Y. Yamanaka, 1996, Double seismic zones, compressional deep trench-outer rise events, and superplumes, in "Subduction Top to Bottom", ed. by G.E. Bebout, Geophys. Monogr. Ser., 96, AGU, Washington, D.C., 347-355.

Shinohara, M., R. Hino, T. Yoshizawa, M. Nishino, T. Sato, and K. Suyehiro, 2005, Hypocenter distribution of plate boundary zone off Fukushima, Japan, Derived from ocean bottom seismometer data, Earth Planets Space., 57, 93-105.
Stauder, W., 1968a, Mechanism of the Rat Island earthquake sequence of February 4, 1965, with relation to island arcs and sea-floor spreading, J. Geophys. Res., 73, 3847-3858.

Stauder, W., 1968b, Tensional character of earthquake foci beneath the Aleutian trench with relation to seafloor spreading, J. Geophys. Res., 73, 7693-7701.

Suyehiro, K., Y. Kaiho, A. Nishizawa, T. Kanazawa, and H. Shimamura, 1990, Seismic upper crust of the Japan Trench inner slope, Tohoku Geophysics. J., 33, 281-305.

海野徳仁・長谷川 昭, 1975, 東北日本にみられる深発 地震面の二層構造について, 地震 2, 27, 125-139.

Umino, N., A. Hasegawa, and T. Matsuzawa, 1995, sP depth phase at small epicentral distances and estimated subducting plate boundary, Geophys. J. Int., 120, 356-366.

Wessel, P. and W.H.F. Smith, 1998, New, improved version of the Generic Mapping Tools released, Eos Trans. AGU, 79, 579.

山中佳子, 2003, 地震学ノートNo.141: 2003 年 10 月 31 日福島県沖地震 (M6.8), <http://www.eri.u-tokyo.ac.jp/ sanchu/Seismo_Note/EIC_News/031031.html>, (参 照 2011-1-27).

Yamanaka, Y. and M. Kikuchi, 2004, Asperity map along the subduction zone in northeastern Japan inferred from regional seismic data, J. Geophys. Res., 109, B07307, doi:10.1029/2003JB002683.

Yamasaki, T. and T. Seno, 2003, Double seismic zone and dehydration embrittlement of the subducting slab, J. Geophys. Res., 108, 2212, doi:10.1029/2002JB 001918. 


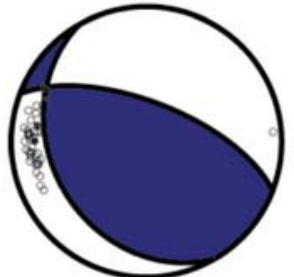

03/05/04 18:59 144.2539 .2833 .4

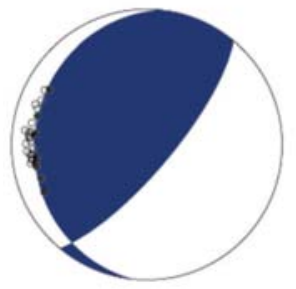

03/05/04 23:26

144.2639 .2831 .9

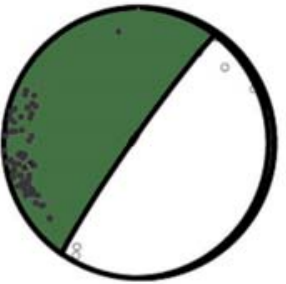

06/06/14 13:13

144.5139 .7025 .6

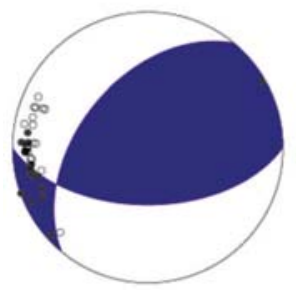

04/03/04 02:57

144.2539 .4242 .9

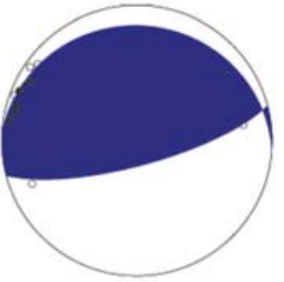

03/01/17 23:58

143.4838 .4036 .9

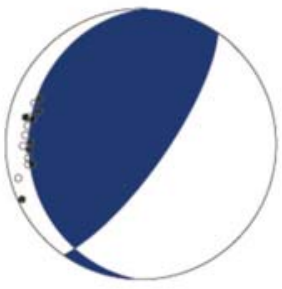

03/05/23 05:14

144.3539 .3326 .7

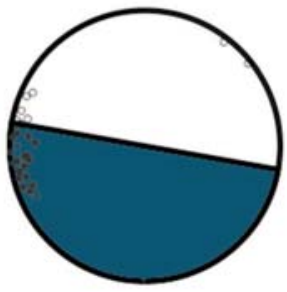

$03 / 10 / 28$ 12:49

143.7039 .6635 .8

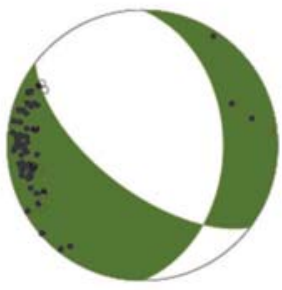

04/05/23 12:14

143.7439 .3529 .9

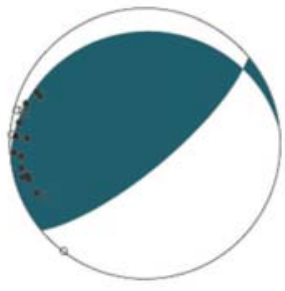

03/02/07 14:19

143.7439 .3937 .1

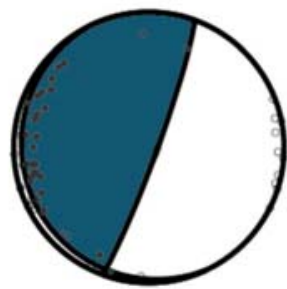

03/07/17 16:46

143.2539 .7133 .1

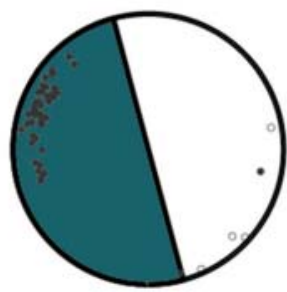

03/11/08 10:57

143.5738 .1734 .6

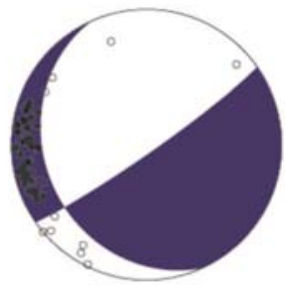

04/07/01 16:55

143.8539 .8039 .0

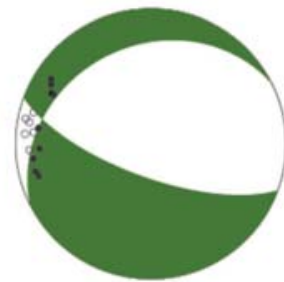

03/04/04 00:53

144.0639 .1538 .3

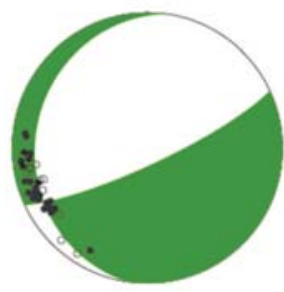

03/08/27 08:56

144.0540 .2138 .5

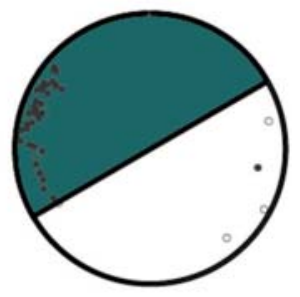

03/11/08 12:03

143.4638 .2034 .0

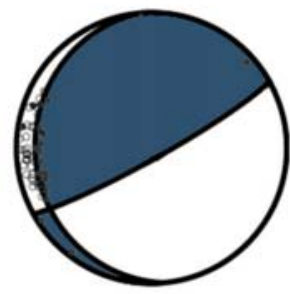

05/12/08 19:44 143.8839 .5139 .0

Fig. A1. Focal mechanism solutions (equal-area projection of the lower hemisphere) determined from Pwave initial motions recorded by onshore and OBS networks. The color scale of each focal mechanism solutions corresponds to the triangle diagram in Fig. 8 (a). The black solid and open circles denote the compression and dilatation of the initial P-wave motions. The focal spheres drawn with solid lines indicate the focal mechanism solutions determined precisely in this study. 


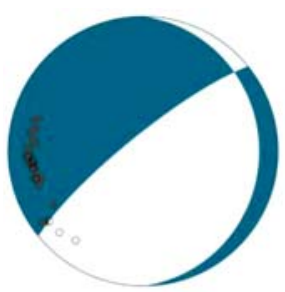

$03 / 10 / 28$ 12:26

143.6839 .6835 .8

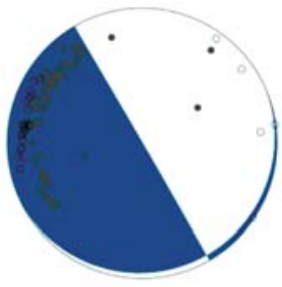

08/12/04 12:10 143.1238 .5410 .6

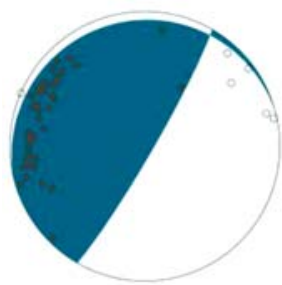

09/03/01 22:56 143.2638 .6310 .8

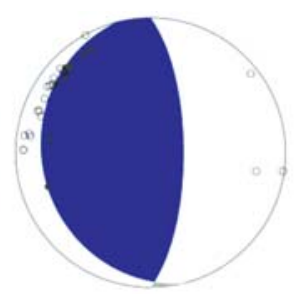

$07 / 02 / 2302: 45$

142.9838 .2611 .0

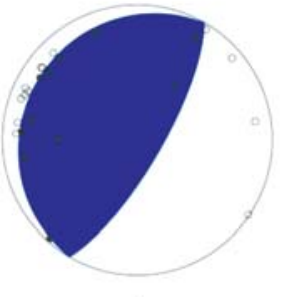

08/12/05 03:42

143.0838 .569 .5

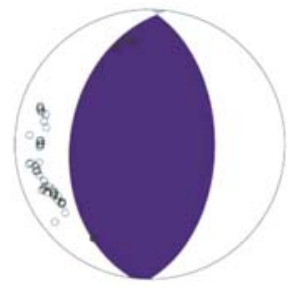

09/05/12 02:02

143.8339 .8414 .9

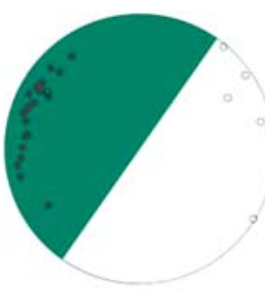

08/12/04 10:42 143.3738 .5210 .2

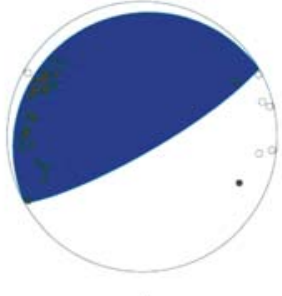

08/12/13 16:20

143.4938 .4512 .6

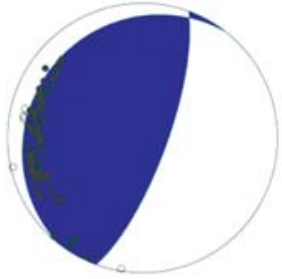

09/06/20 11:52

143.3639 .099 .3

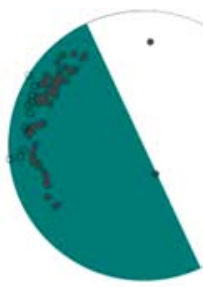

08/12/04 08:16

143.2238 .5311 .5

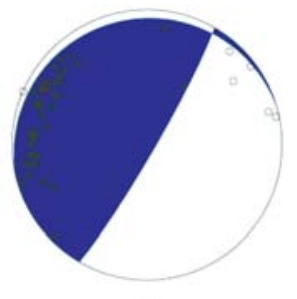

09/06/20 11:52

143.3639 .099 .3

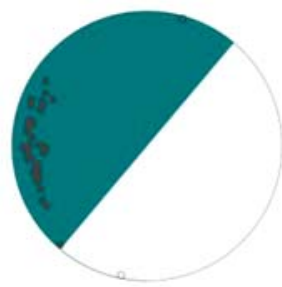

09/06/21 19:24 143.4139 .1610 .5

Fig. A1. Continued. 